\title{
Year-round population dynamics of Limacina spp. early stages in a high-Arctic fjord (Adventfjorden, Svalbard)
}

\author{
Lauris Boissonnot ${ }^{1,2,3}$ (]) Peter Kohnert ${ }^{4,5} \cdot$ Benedikt Ehrenfels $^{6,7} \cdot$ Janne E. Søreide $^{3} \cdot$ Martin Graeve $^{1}$. \\ Eike Stübner ${ }^{3} \cdot$ Michael Schrödl $^{4,5,8} \cdot$ Barbara Niehoff $^{1}$
}

Received: 7 January 2020 / Revised: 16 April 2021 / Accepted: 8 June 2021 / Published online: 23 June 2021

(c) The Author(s), under exclusive licence to Springer-Verlag GmbH Germany, part of Springer Nature 2021

\begin{abstract}
The thecosome pteropods Limacina helicina and L. retroversa are important contributors to the zooplankton community in high-latitude environments but little is known about their distribution and life cycle under polar conditions. We collected the early life stages $(<1 \mathrm{~mm})$ of the thecosome population in 2012 and 2013 at a bi-weekly to monthly resolution in fjord highly influenced by Arctic waters as well as Atlantic inflows (Adventfjorden, Svalbard, $78^{\circ} \mathrm{N}$ ), together with environmental parameters. L. retroversa only occurred episodically, in association with the inflow of Atlantic water, with low numbers and random size distributions. This suggests that this boreal species does not fulfill its life cycle in Adventfjorden. In contrast, young specimens of L. helicina were present during the entire study. Veligers hatched in late summer/autumn and measured $0.14 \mathrm{~mm}$ on average. They grew with rates of $0.0006 \mathrm{~mm}^{-1} \mathrm{y}^{-1}$ over the $10-11$ months of development. Only thereafter, growth accelerated by one order of magnitude and maximal rates were reached in autumn $\left(0.0077 \mathrm{~mm} \mathrm{day}^{-1}\right)$. Our results indicate that L. helicina reaches a size of $1 \mathrm{~mm}$ after approximately 1.5 years in Adventfjorden. We therefore suggest that L. helicina overwinters the first year as a small juvenile and that it needs at least 2 years to reach an adult size of $5 \mathrm{~mm}$ in Adventfjorden. This reveals an complex and delicate aspect of the life-cycle of L. helicina and further research is needed to determine if it makes the population especially vulnerable towards climate changes.
\end{abstract}

Keywords Thecosome pteropods $\cdot$ Veligers and juveniles $\cdot$ Distribution $\cdot$ Growth rate $\cdot$ Svalbard $\cdot$ Polar conditions

\section{Introduction}

Shelled pteropods (thecosomes) are significant components of polar marine ecosystems. They can dominate the zooplankton community at times (Blachowiak-Samolyk et al. 2008) and are considered key species in the pelagic food web. They graze on phytoplankton and other small particles (Perissinotto 1992; Noji et al 1997; Bernard and Froneman

Lauris Boissonnot

lauris@aqua-kompetanse.no

1 Alfred-Wegener Institute Helmholtz Centre for Polar and Marine Research, Am Handelshafen 12, 27570 Bremerhaven, Germany

2 Aqua Kompetanse AS, Havbruksparken, Storlavika 7, 7770 Flatanger, Norway

3 University Centre in Svalbard, N-9171 Longyearbyen, Norway

4 SNSB Bavarian State Collection of Zoology, Section Mollusca, Münchhausenstr. 21, 81247 Munich, Germany
2009) and are in turn preyed upon by large zooplankton, birds, fish and marine mammals (Hopkins and Torres 1989; Lalli and Gilmer 1989; Lancraft et al. 1991; Hunt and al 2008). Thecosomes also have a significant role in the production and export of organic matter and calcium carbonate (Berner and Honjo 1981; Bathmann et al. 1991; Hunt et al. 2008). During the productive season, they may contribute up to $72 \%$ of the organic carbon export in the Southern Ocean

5 Department Biologie II, Biozentrum, Ludwig-Maximilians-U niversität, Großhaderner Str. 2, 82152 Planegg-Martinsried, Germany

6 Department Surface Waters-Research and Management, Swiss Federal Institute of Aquatic Science and Technology (EAWAG), Kastanienbaum, Switzerland

7 Institute of Biogeochemistry and Pollutant Dynamics, Swiss Federal Institute of Technology (ETH) Zurich, Zurich, Switzerland

8 Center of Geobiology and Biodiversity Research, Lud wig-Maximilians-Universität, Richard-Wagner-Str. 10, 80333 Munich, Germany 
(Manno et al. 2010). Part of this flux is related to the excretion of feacal pellets that sink to deeper layers (Gilmer and Harbison 1991; Accornero et al. 2003) as well as pseudofaeces, which are the result of the degradation of mucus nets used for grazing (Harbison and Gilmer 1986). Due to the production of aragonite shells, thecosomes also substantially contribute to the calcium carbonate export in polar waters (Byrne et al. 1984; Tsurumi et al. 2005; Bauerfeind et al. 2014; Buitenhuis et al. 2019).

Rising $\mathrm{CO}_{2}$ concentrations might not only shift the areas of distributions of the different thecosome pteropod species through climate change and alterations of ocean currents, but also impact their survival success on a more fundamental level their very thin aragonite shell makes thecosome pteropods highly sensitive to acidification (e.g., Comeau et al. 2012; Lischka and Riebesell 2012; Bednaršek et al. 2014). Both, climate change and ocean acidification are particularly rapid in polar regions (IPCC 2019), exposing thecosomes to dramatic alterations. The combination of $\mathrm{pCO}_{2}$ increase and $\mathrm{pH}$ decrease is expected to lead to a reduced growth due to a limited calcification and could result in a decline of the population in the next decades with possible cascading impacts on the entire Arctic pelagic food chain and the carbon pump (Lischka et al. 2011; Lishcka and Riebesell 2012; Manno et al. 2012). Although the physiological response of thecosomes to climate change stressors is well documented, there is a major lack of knowledge regarding their life history, especially in Arctic fjords characterized by polar conditions. The population structure, the longevity of individuals, and the growth rates are decisive parameters for the resilience against environmental changes.

In Arctic ecosystems, two species of thecosome pteropods are present, Limacina helicina and L. retroversa (Kattner et al. 1998; Hop et al. 2006; Bauerfeind et al. 2014). Both species live in a narrow range of temperature and salinity, which make them useful biological indicators of water mass origins and environmental changes. Limacina helicina inhabits polar waters and is adapted to temperatures between -1.6 and $4{ }^{\circ} \mathrm{C}$ (Conover and Lalli 1972; Hopkins 1985, 1987). L. retroversa is a boreal species, thriving at temperatures ranging from 2 to $7^{\circ} \mathrm{C}$ (Chen and Bé 1964; van der Spoel 1967; Bé and Gilmer 1977). L. helicina is a prominent member of the Arctic zooplankton community while $L$. retroversa occurs episodically when introduced by Atlantic water masses (Hop et al. 2006; Walkusz et al. 2009). During the last decade, a shift from a dominance of L. helicina to $L$. retroversa has been observed in the Fram Strait as a consequence of increased inflow of warm Atlantic water (Bauerfeind et al. 2014).

Several studies have been conducted to assess the population dynamics of L. helicina, but their findings differ considerably and make it difficult to draw general conclusions. Data from high- and temperate latitudes in both hemispheres suggest between 1 and 2 generations per year, longevity from 1 to 3 years, a maximum size range from 3.7 to $>10 \mathrm{~mm}$ and continuous or discrete reproduction once or twice a year (summarized in Table 1 in Wang et al. 2017). These large variations can, at least in part, be attributed to differences in environmental conditions related to the geographical locations of the sampling sites. In the Svalbard Archipelago, data are only available from Kongsfjorden, Svalbard, which is however strongly influenced by Atlantic water (Svendsen et al. 2002), and thus mirrors boreal rather than polar conditions. In this fjord, L. helicina has a live span of one year and reproduces once per year, in late summer/autumn (Gannefors et al. 2005). The maximum size of the individuals found in Kongsfjorden is $13 \mathrm{~mm}$, which is typical of sub-Arctic regions (Lalli and Wells 1978; Gilmer and Harbison 1991), but 2 to 3 times bigger than in the Arctic Ocean (Kobayashi 1974). In winter, growth apparently ceases and resumes in spring (Lischka et al. 2011; Lischka and Riebesell 2012; Gannefors et al. 2005; Comeau et al. 2010). In contrast to Kongsfjorden, the population dynamics of L. helicina in Adventfjorden, Svalbard has not yet been documented, except for yearly observations of swarms composed of large individuals ( $>10 \mathrm{~mm})$ between June and August (pers. obs.). This fjord is mainly influenced by Arctic water while Atlantic waters reach the fjord only occasionally (Nilsen et al. 2008; Cottier et al. 2010), allowing to study the life cycle of L. helicina under polar conditions.

The life cycle of $L$. retroversa (maximum size of $3 \mathrm{~mm}$, Hsiao 1939) has been studied less than that of L. helicina. Some studies conducted in sub-polar environments suggested a 1-year life cycle, with one reproductive event in spring (Hsiao 1939) or in autumn (Meinecke and Wefer 1990). However, constant reproductive activity throughout the year has been considered the most likely, with an intense spawning event in spring and another one in autumn (Lebour 1932; Dadon and De Cidre 1992). The Arctic represents the northern limit of $L$. retroversa's area

Table 1 Samples collected for the molecular identification of Limacina helicina and L. retroversa

\begin{tabular}{llll}
\hline Date & $\begin{array}{l}\text { Number of } \\
\text { individuals }\end{array}$ & Size range $(\mathrm{mm})$ & Depth range $(\mathrm{m})$ \\
\hline 6 September 2012 & 6 & $0.11-0.34$ & $25-0$ \\
6 September 2012 & 6 & $0.15-0.24$ & $65-25$ \\
$\begin{array}{l}\text { 19 September } \\
\quad 6\end{array}$ & $0.13-0.33$ & $25-0$ \\
$\quad$ 19 September & 6 & $0.23-0.34$ & $65-25$ \\
$\quad$ 2012 & & & \\
18 October 2012 & 6 & $0.24-0.42$ & $25-0$ \\
18 October 2012 & 6 & $0.20-0.50$ & $65-25$ \\
12 December 2012 & 6 & $0.14-0.38$ & $25-0$ \\
12 December 2012 & 10 & $0.15-0.38$ & $65-25$ \\
\hline
\end{tabular}


of distribution; but it is still unknown, whether or not $L$. retroversa is an expatriate or is able to successfully complete its life cycle in these waters (Lischka and Riebesell 2012).

One limitation to better understanding the life cycles of L. helicina and L. retroversa is that previous works focused mainly on larger individuals (at the exception of Lischka and Hagen 2016 and Lischka and Riebesell 2012). The reason for this restriction to large individuals may be related to sampling limitations and to the fact the veligers and juveniles of L. helicina and L. retroversa are morphologically indiscernible (Lischka, pers. Comm.). However, they can be clearly identified when using molecular markers (Kohnert, unpublished data). In addition, previous studies focusing on Arctic regions were conducted either on short periods or with sparces temporal resolutions, which made it difficult to interpolate results to a more complete understanding of thecosomes life dynamics.

The goal of this study was to examine the life history of thecosomes in a fjord predominantly influenced by Arctic waters by monitoring their population structure for 2 years. Our research objectives were in particular to (1) apply barcoding methods for the identification of Limacina spp. Early veliger and juvenile stages, (2) relate the occurrence of L. helicina and L. retroversa to environmental parameters and (3) determine the annual growth of veligers and juveniles by measuring shell sizes in a high temporal resolution year-round.

\section{Materials and methods}

\section{Study region and environmental conditions}

The study was conducted during two consecutive years from January 2012 to December 2013 in Adventfjorden at the time-series Isfjorden-Adventfjorden sampling station (Stn. IsA: $78.261^{\circ} \mathrm{N}, 15.542^{\circ} \mathrm{E}$, Fig. 1). Adventfjorden is small side-fjord of Isfjorden, on the west coast of Svalbard. The fjord is $8.3 \mathrm{~km}$ long, $3.4 \mathrm{~km}$ wide and $80 \mathrm{~m}$ deep. It is mainly exposed to the cold Arctic-derived East Spitsbergen Current. Occasionally, it can experience inflow of warm Atlantic Water from the West Spitsbergen Current, which penetrates into the fjord to an extent that shows great annual variations (Nilsen et al. 2008; Cottier et al. 2010). Two larger and several smaller rivers discharge freshwater and sediments in Adventfjorden during the main melting season in summer (Leikvin and Evenset 2009).

Salinity, temperature, and density as well as in-situ Chlorophyll $a(\mathrm{Chl} a)$ fluorescence were measured at each sampling event at Stn IsA, from bottom to surface using a hand-held CTD (CTD, SAIV A/S) with an attached fluorometer. Water masses were defined according to Svendsen et al. (2002). Air temperature, precipitation, wind direction and wind speed data were provided by the Norwegian Meteorological Institute. This data set includes measurements conducted every $6 \mathrm{~h}$ from January 2012 to December 2013 at the station Svalbard Lufthavn, $\left(78.242^{\circ} \mathrm{N}, 15.502^{\circ} \mathrm{E}\right.$, Fig. 1). Data were analyzed using the free software R (R Core Team
Fig. 1 Map of the sampling station Isfjorden-Adventfjorden (IsA; $78.261^{\circ} \mathrm{N}, 15.542^{\circ} \mathrm{E}$ ), and the meteorological station Svalbard Lufthavn $\left(78.242^{\circ} \mathrm{N}\right.$, $\left.15.502^{\circ} \mathrm{E}\right)$. The dashed arrow represents the influence of the Arctic water masses and the plain arrow represents the general influences of Atlantic water masses. Open arrows indicate fresh water influences from rivers into Adventfjorden (modified from Stübner et al. 2016)

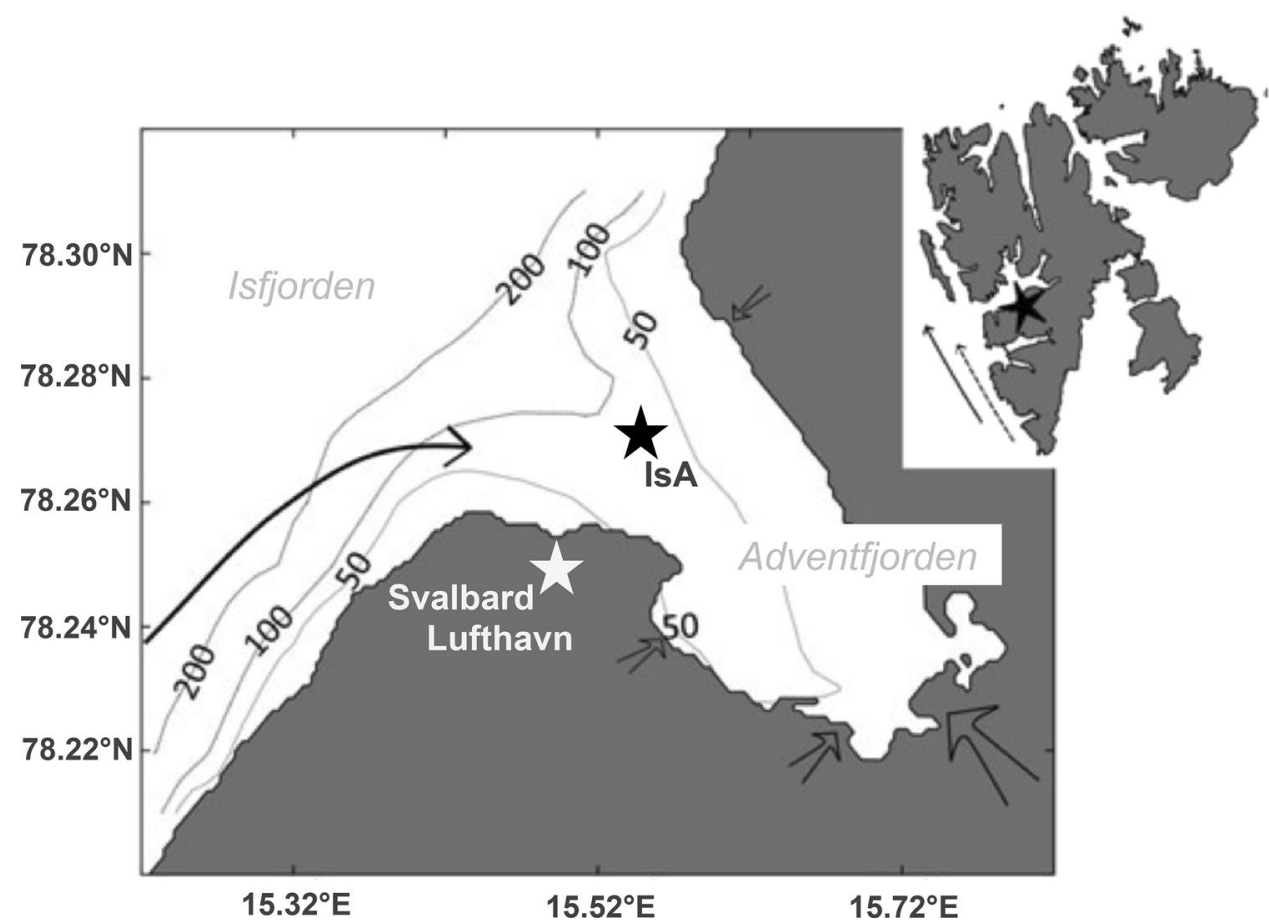


2019), interpolations were made with the package akima (Akima et al. 2020).

\section{Sampling}

The zooplankton community was sampled once a month and when the weather conditions allowed, twice a month. Sampling was conducted at Stn IsA (80 m deep), on board a small boat (PolarCirkel, Akva Group) in 2012 and 2013. Zooplankton were collected between 08:00 and 14:00 by vertical hauls from 65 to $25 \mathrm{~m}$ (deep layer) and 25 to $0 \mathrm{~m}$ (surface layer) using a WPII closing net (63 $\mu \mathrm{m}$ mesh size, $0.25 \mathrm{~m}^{2}$ net opening, Hydro-Bios). These nets efficiently capture Limacina spp. Of small size, which are present in relatively high abundances. The densities of large Limacina specimen are generally low in this fjord and their occurrence is restricted to June-August (pers. obs.). It was, thus, not very likely to capture them by vertical tows with fine mashes, and accordingly, they were not found in our samples. The samples were immediately fixed in a seawater/ formaldehyde (4\%) solution for later determination of the species and size composition. Additional samples were fixed in ethanol (70\%) and stored dark and cold $4{ }^{\circ} \mathrm{C}$ for subsequent molecular analyses. No flowmeter was used, and volume filtered was calculated from net opening and sampling depth, assuming $100 \%$ filtration efficiency.

Limacina spp. Specimens were measured to $0.01 \mathrm{~mm}$ precision (shell diameter) and counted under a Leica MZ12 Stereomicroscope. Identification to the species level was done in parallel to counting of specimens larger than $0.5 \mathrm{~mm}$, considering that $L$. retroversa has a pointed spiral shell while L. helicina has a flat shell (van der Spoel and Dadon 1999). Morphological identification was not possible for specimens smaller than $0.5 \mathrm{~mm}$ since first life stages of both $L$. retrovers $a$ and $L$. helicina have a flat shell (Lischka, pers. Comm).

\section{Molecular analyses}

To determine the smallest individuals to species level, 52 veliger $(0.11-0.41 \mathrm{~mm})$ were randomly picked from the samples fixed in $70 \%$ ethanol (Table 1). Due to their small size, whole individuals were used to extract genomic DNA. We followed the CTAB extraction method (Knebelsberger and Stöger 2012) with a modified collection of dissolved DNA in a spin column from a NucleoSpin Tissue set (Macherey-Nagel $\mathrm{GmbH} \& \mathrm{Co}$ ) to assure maximum DNA recovery (Kohnert unpublished data). Nuclear Histone 3 marker (H3) contains a diagnostic nucleotide to distinguish between L. helicina and L. retroversa, as base 307 is $\mathrm{G}$ in L. helicina and $\mathrm{T}$ in $L$. retroversa (Kohnert, unpublished data). $\mathrm{H} 3$ was amplified in $0.2 \mathrm{ml}$ illustra ${ }^{\mathrm{TM}}$ PuReTaq ${ }^{\mathrm{TM}}$ Ready-To-Go ${ }^{\mathrm{TM}}$ PCR tubes (GE Healthcare) with $23 \mu \mathrm{l}$ molecular water, $1 \mu \mathrm{l}$ of template DNA and $0.5 \mu \mathrm{l}$ of forward and reverse primer $(10 \mathrm{pm} / \mu \mathrm{l})$, respectively. We used the primers $\mathrm{H} 3 \mathrm{aF}$ : 5'-ATG GCT CGT ACC AAG CAG ACV GC-3' and H3aR: 5'-ATA TCC TTR GGC ATR ATR GTG AC-3' (Colgan et al. 2000) with the following PCR settings: initial denaturation for 5 min. at $94{ }^{\circ} \mathrm{C}$ followed by 36 cycles of denaturation for $45 \mathrm{~s}$ at $94{ }^{\circ} \mathrm{C}$, annealing for $50 \mathrm{~s}$ at $45^{\circ} \mathrm{C}$, elongation and extension at $72{ }^{\circ} \mathrm{C}$ for $200 \mathrm{~s}$ and a final elongation step at $72{ }^{\circ} \mathrm{C}$ for $10 \mathrm{~min}$. Successful amplicons were purified using a DNA Clean \& Concentrator Kit (ZYMO Research) according to the manufacturer's manual with a final elution volume of $15 \mu$. Molecular analyses were performed at the Bavarian State Collection of Zoology (ZSM Munich).

Sequencing was performed using Big Dye 3.1 with $5 \mu \mathrm{l}$ diluted $(2 \mathrm{pm} / \mu \mathrm{l})$ amplification primers and $2 \mu \mathrm{l}$ of purified PCR-product. Sequences were edited in Geneious R8 (8.1.7.) (www.geneious.com, Kearse et al. 2012) and aligned with the implemented Mafft plugin (Katoh et al. 2009). As a reference, Limacina spp. Sequences generated from clearly identifiable adult specimens of the respective species were included. These samples were collected in Svalbard ( $L$. helicina) and Bergen (L. retroversa). Genetic vouchers are stored at the ZSM Munich. A 336 bp long sequence was successfully amplified for 39 specimens. 11 samples failed in PCR or resulted in sequences that could not be assembled/ aligned, rendering a success rate of $78 \%$.

\section{Identification of cohorts and growth rates}

To examine the size-distribution patterns of the thecosome populations, the shell diameters of each L. helicina and $L$. retroversa were displayed in size-frequency histograms for each sampling date (Fig. 2). Replicates from deep (65-25 m) and surface $(25-0 \mathrm{~m})$ layers were pooled, since no size difference was detectable (L. helicina: $t$-test, $t_{47.15}=1.8595$, $p=0.0692 ;$ L retroversa: $t$-test, $t$-test, $t_{47.612}=0.781$, $p=0.4387$ ). To further investigate the growth rates, the next step was to identify different cohorts that possibly cooccurred at all sampling dates. We used the package mixdist (Macdonald and Du 2018) in the free software R (R Core Team 2019) to fit mixture distribution models to the shell diameter distributions of L. helicina $(n=3620)$ and L. retroversa $(n=220)$ separately. Based on the best fit for the mixture distribution model, samples were separated into 20 size classes ranging from 0.1 to $1 \mathrm{~mm}(0.05 \mathrm{~mm}$ intervals). Initial values (frequency of each size class) were implemented, and parameters (mean values and standard deviations of sub-distributions) were estimated by the Kernel density estimation. This non-parametric method estimates the probability density function of a random discrete variable (Botev et al. 2010). From the Kernel density estimation, and the size-range of individuals captured by our nets, we identified three cohorts of L. helicina throughout the study 


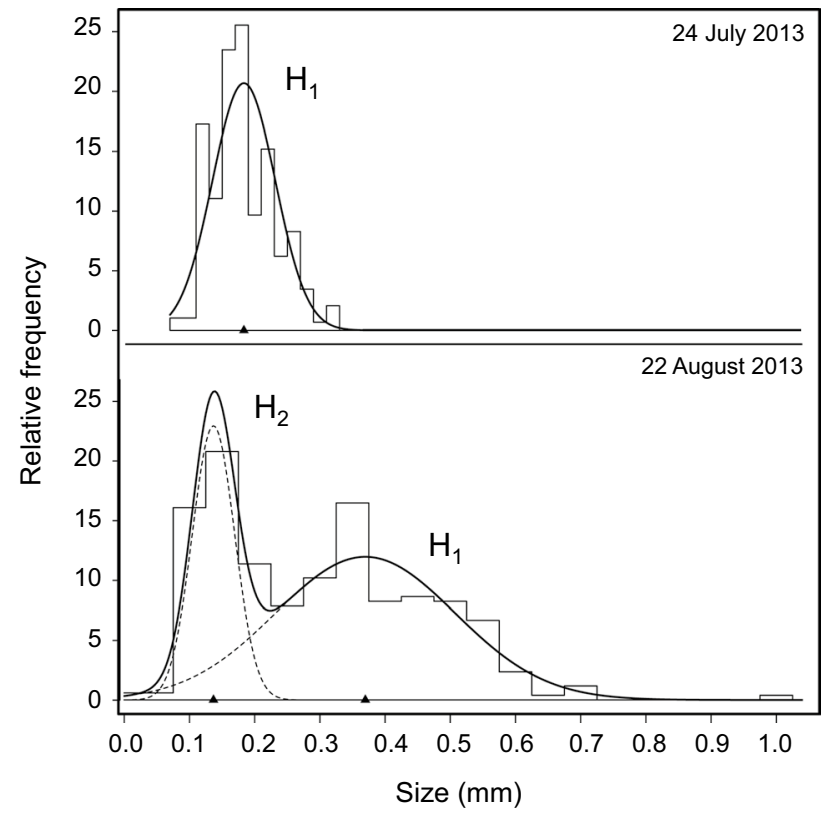

Fig. 2 Size-frequency histograms of Limacina helicina caught on 24 July 2013 and 22 August 2013 as an example of the population structure reflected by the samples. This configuration is the same in 2012 and 2013, with 1 cohort present in late winter to summer (represented by $H_{1}$ in 2013) and 2 cohorts in autumn/early winter $\left(H_{1}\right.$ and $H_{2}$ in 2013). Overlaying solid lines are best fitting mixture models. Mean shell diameter values are represented by triangles. Dotted curved lines represent the different cohorts

period in total with one or two cohorts being present at the same time (Fig. 2). From 27 January to 19 September 2012, size frequency followed a normal distribution, representing one cohort referred to as $\mathrm{H}_{0}$. Between 19 September and 15 November 2012, a bimodal distribution was observed, corresponding to the cohort $\mathrm{H}_{0}$ and a new cohort, named $\mathrm{H}_{1}$, which was characterized by smaller sizes. On 15 November $2012 \mathrm{H}_{0}$ disappeared from the samples, possibly due to the capacity of grown individuals to escape from the nets. $\mathrm{H}_{1}$ was then the only cohort until 13 August 2013 when another cohort, $\mathrm{H}_{2}$, appeared. Both cohorts co-occurred until the end of our study, as revealed by the bimodal distribution of sizes. In contrast to L. helicina, shell size distribution of L. retroversa was heterogeneous and inconsistent, thus no distinct cohorts could be identified in this species.

Growth rates of L. helicina were calculated based on the estimated cohorts and calculated as (1), according to Bednaršek et al. (2012):

(L) $G_{H_{n, t 1 \rightarrow 2}}=\frac{L_{t_{2}}-L_{t_{1}}}{t_{2}-t_{1}}$

where $H_{n}$ is the cohort of interest, $L$ is the mean shell diameter in mm (estimated by the Kernel density estimation), and $t$ is the time (in days). The statistical significance $(p)$ of seasonal growth rates was tested with a Fisher test (ANOVA), using locally linear regressions. Significance level was set to $p<0.05$.

\section{Analyses of thecosome densities and growth rates}

Statistical analyses were performed using the free software $R$ ( $R$ Core Team 2019). To assess the environmental forcing on the thecosomes densities and growth rates in the entire water column, 2 principal component analyses (PCA) were performed using the R package FactoMineR (Lê et al. 2008). The environmental data (water properties and meteorology) as well as time (expressed as day of the year) were computed as active variables (used for the determination of principal components). Seawater densities were not included in the PCA because they were computed from temperature (T) and salinity (S), and the strong correlation among these variables could alter PCA results. Biological data were added as supplementary variables (projected on the results drawn from active variables). Thecosome densities were imputed as biological data as well as growth rates of the cohorts $\mathrm{H}_{0}$ and $\mathrm{H}_{1}$ of L. helicina. Growth rates of $\mathrm{H}_{2}$ could not be included in the analysis because there was too little data. Missing values were estimated with the package missMDA (Husson and Josse 2010) using the relations between all variables from 2 dimensions of the PCA.

\section{Results}

\section{Environmental conditions}

Adventfjorden was influenced by Arctic water and Atlantic water in similar seasonal succession in 2012 and 2013 (Fig. 3). Arctic water $(\mathrm{S}<34.7)$ mostly prevailed in the fjord. Between January and June, the water was characterized by cold temperatures $\left(\mathrm{T}<1{ }^{\circ} \mathrm{C}\right)$, with the exception of a warm and saline Atlantic water inflow in March/April $2012\left(\mathrm{~T}>1{ }^{\circ} \mathrm{C}\right.$ and $\left.\mathrm{S}>34.7\right)$. From June to September, river runoff led to stratification of the water column, with a warm and low saline freshwater layer in the upper $10 \mathrm{~m}\left(\mathrm{~T}>8^{\circ} \mathrm{C}\right.$ and $\mathrm{S}<33$ ) while deep layer was still characterized by cold Arctic Water. From September on, the water column started to mix, leading to the formation of an intermediate layer that remained until the end of the year $(34<\mathrm{S}<34.7)$. In addition, Atlantic water $\left(\mathrm{T}>1{ }^{\circ} \mathrm{C}\right.$ and $\left.\mathrm{S}>34.7\right)$ penetrated in the fjord in September-November both in 2012 and 2013, in the deep layers.

$\mathrm{Chl} a$ concentrations as indicated by fluorescence measurements were low in both years from January to mid-April (Fig. 3). From then on, they increased to maximum values of $4 \mu \mathrm{g} \mathrm{L}^{-1}$ in mid-May 2012 and $7 \mu \mathrm{g} \mathrm{L}^{-1}$ in late April 2013, on average. Chl $a$ concentrations remained high in the entire 

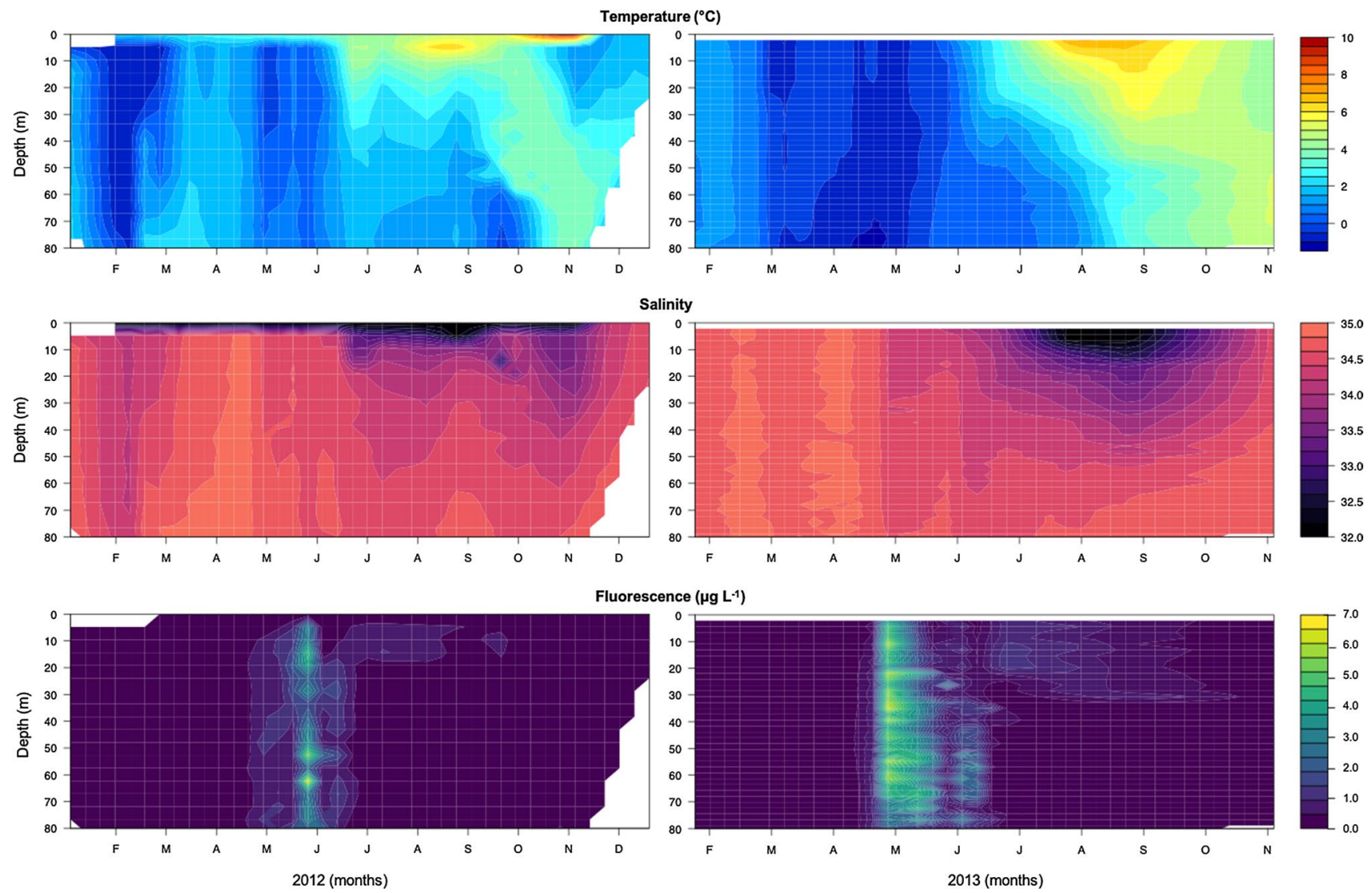

Fig. 3 Contour plots of environmental variables at the sampling station Isfjorden-Adventfjorden (IsA). Temperature (upper panel), salinity (middle panel) and fluorescence as a proxy for Chlorophyll $a$ (lower panel) were linearly interpolated between measurements

water column until June. Between July and September, Chl $a$ values decreased and showed a distinct near-surface maximum. From September/October on, Chl $a$ concentrations were low again $\left(<0.1 \mu \mathrm{g} \mathrm{L}^{-1}\right)$.

\section{Population structure}

\section{Species identification}

Among 52 individuals allocated to molecular analyses, only 1 was identified as $L$. retroversa (6 September 2012, deep layer), indicating that $98 \%$ of the specimens $<0.5 \mathrm{~mm}$ were L. helicina (see Online Resource 1 for Genbank accession numbers). Therefore, for the following analyses, we decided to consider all individuals (also those $<0.5 \mathrm{~mm}$ ) with flat shell as L. helicina.

\section{Population densities}

L. helicina was found on most sampling days between January 2012 and October 2013 (Fig. 4a). In 2012, an average of 108 individuals $\mathrm{m}^{-3}$ were found in January and February. In spring and summer, densities did not exceed 50 ind. $\mathrm{m}^{-3}$, except for July when $>300$ ind. $\mathrm{m}^{-3}$ were found. In September 2012, there was a sudden increase in density to $>1500$ ind. $\mathrm{m}^{-3}$ whereas in October-December less than 250 ind. $\mathrm{m}^{-3}$ were counted. In 2013, the densities in winter and spring were much lower than in the previous year, varying between 0.4 and 4 ind. $\mathrm{m}^{-3}$ from January to June. In July, the numbers increased again, reaching the yearly maximum of 1700 ind. $\mathrm{m}^{-3}$ in September. In congruence with the previous year, the numbers decreased in October to 270 ind. $\mathrm{m}^{-3}$. The abrupt increase in density of young stages around September 2012 and 2013 suggests that hatching occurred at this time of the year. In contrast, the dramatic decrease in density suggests high mortality rates between September and October in both years (50 ind. day ${ }^{-1}$ in 2012 and 46 ind. day $^{-1}$ in 2013) whereas mortality was negligible during the rest of the sampling period. Throughout the sampling period, twice as many individuals were found in the surface layer (25-0 $\mathrm{m}$ ) as compared to the deeper layer (65-25 $\mathrm{m})$, and in September, individuals were even $>20$ times more abundant in surface than deep waters.

L. retroversa was only observed from 19 September 2012 to 11 February 2013, with an average of 14 ind. $\mathrm{M}^{-3}$. Individuals were 2 times more dense in deep waters as compared 
Fig. 4 Densities of (a) Limacina helicina and (b) L. retroversa in the surface $(25-0 \mathrm{~m})$ and deep $(65-25 \mathrm{~m})$ layers at IsfjordenAdventfjorden sampling station (IsA), in 2012 and 2013. Densities were calculated for the entire population (all sizes combined). L. retroversa was only found between 19 September 2012 and 11 February 2013. Arrows represent the dates/ periods when no Limacina was found in the samples
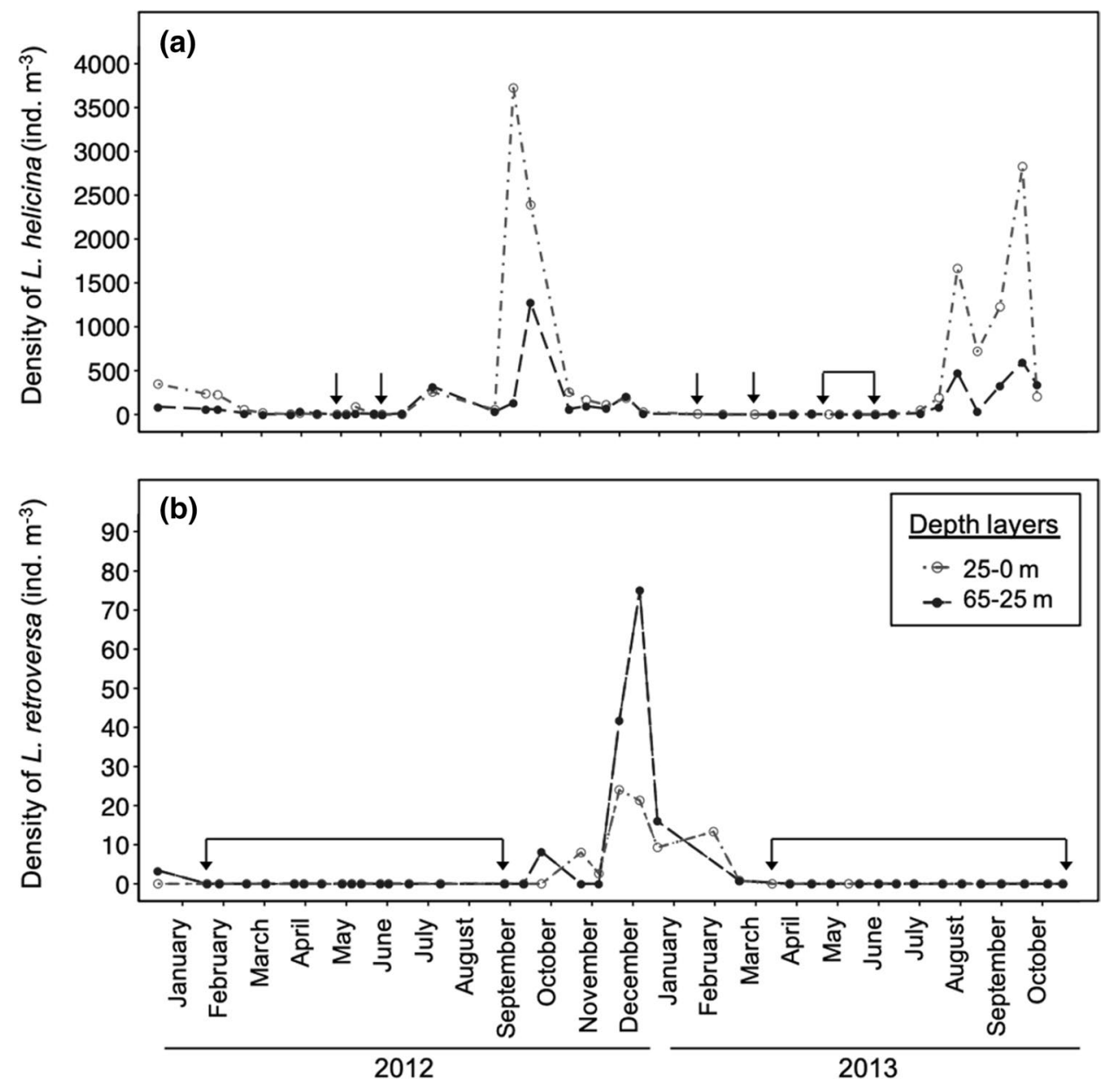

to surface. A peak of density was observed on 29 November 2012, with 75 ind. $\mathrm{M}^{-3}$ in the surface layer and 21 ind. $\mathrm{m}^{-3}$ in the deep layer (Fig. 4b).

The first and second principal components of the PCA performed on environmental variables explained $34 \%$ and $16 \%$ of the variance in the dataset, respectively (Fig. 5). Water temperature, wind speed and time were positively correlated, while being negatively correlated with salinity. L. helicina densities were positively correlated with water temperature and Julian day, while they were negatively correlated with salinity. L. retroversa had no strong correlation with any environmental variables.

\section{Size distribution and growth}

The mixed distribution model applied to the population data of young L. helicina showed that the population was composed of either 1 or 2 cohorts at a time (Fig. 6). The cohort $\mathrm{H}_{0}(n=905)$ was observed from the start of our study, on 27 January 2012. The estimated mean size at this date was $0.14 \pm 0.05 \mathrm{~mm}(n=140)$, with a minimum shell diameter of $0.11 \mathrm{~mm}$ (Fig. 7). In the winter months (27 January to 29
March 2012), the growth of these individuals was slow, at a rate of $0.0002 \mathrm{~mm} \mathrm{day}^{-1}$ (ANOVA, $F_{227}=3.425, p=0.0355$ ) (Fig. 6). By the end of winter, the shell diameter had reached only $0.15 \pm 0.05 \mathrm{~mm}(n=89)$. The growth was still slow in spring/early summer (29 March to $6 \mathrm{July}$, at a rate of $0.0004 \mathrm{~mm} \mathrm{day}^{-1}$ (ANOVA, $\left.F_{276}=3.161, p=0.0465\right)$ resulting in a size of $0.19 \pm 0.06 \mathrm{~mm}(n=155)$ in the beginning of July. In summer, (6 July to 19 September), individuals grew at a rate of $0.0011 \mathrm{~mm}^{-1 a y}{ }^{-1}\left(A N O V A, F_{355}=133.5\right.$, $p<0.0001)$ reaching a shell diameter of $0.24 \pm 0.09 \mathrm{~mm}$ $(n=202)$. In autumn (19 September to 15 November), individuals showed a maximum growth rate of $0.0066 \mathrm{~mm}^{\text {day }}{ }^{-1}$ (ANOVA, $\left.F_{454}=980.8, p<0.0001\right)$. During this season, sizes more than doubled, reaching $0.81 \pm 0.08 \mathrm{~mm}(n=45)$ in November. From January to November 2012, the shells thus increased sixfold in diameter.

The cohort $\mathrm{H}_{1}(n=1703)$ appeared on 19 September 2012 and had an estimated mean size of $0.13 \pm 0.06 \mathrm{~mm}$ $(n=319)$, with minimum shell diameter of $0.05 \mathrm{~mm}$ (Fig. 8). In the following months (19 September to 15 November), $\mathrm{H}_{1}$ grew at a rate of $0.0012 \mathrm{~mm} \mathrm{day}^{-1}$ (ANOVA, $F_{626}=1.778, p=0.0478$ ) (Fig. 6). In the period 


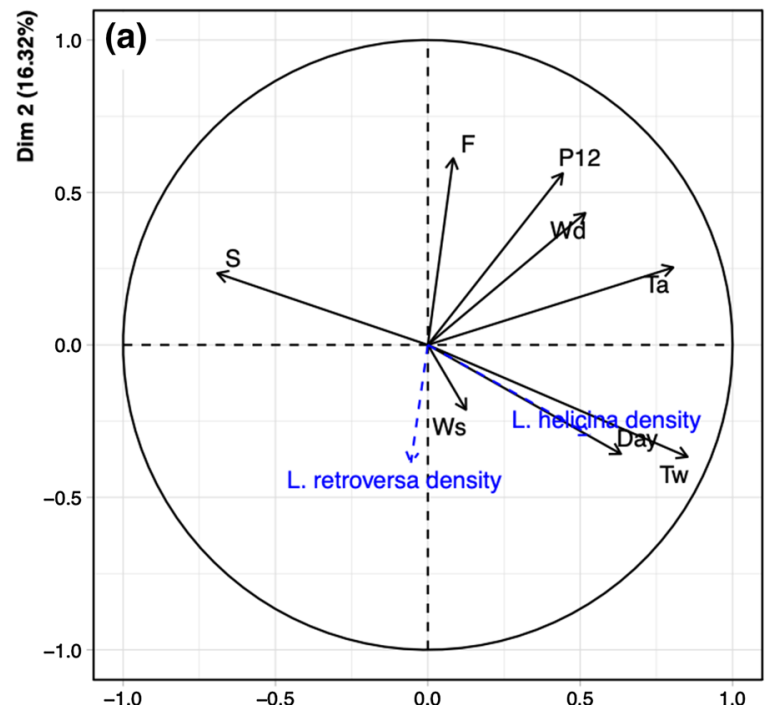

Fig. 5 Principal component analysis of environmental variables in Adventfjorden. Water properties are imputed as $T w$ water temperature, $S$ salinity and $F$ fluorescence. Meteorological data include $T a$ air temperature, $P 12$ precipitations in the last $12 \mathrm{~h}, W d$ wind direction

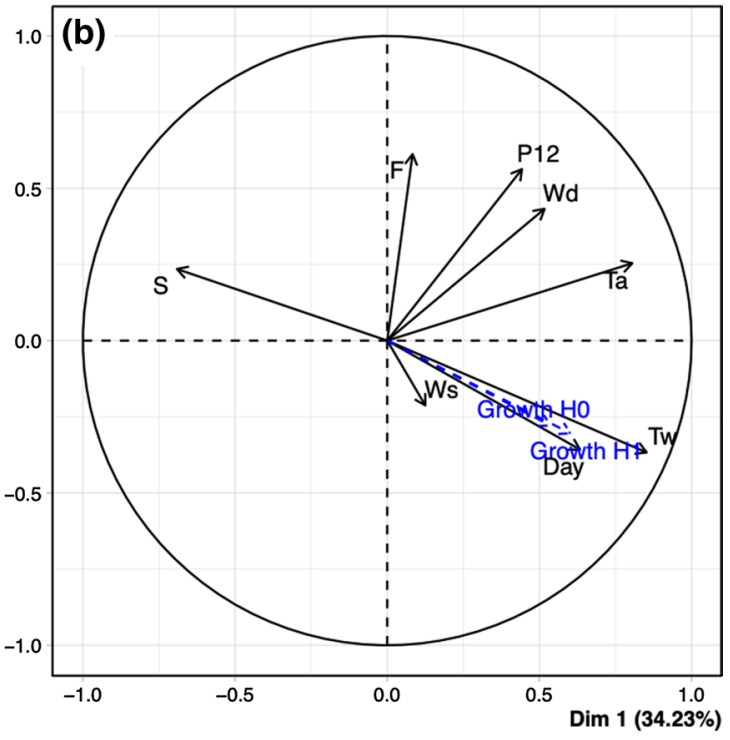

and Ws wind speed, Day Day of the year. Biological data are imputed as supplementary variables, they represent a densities of Limacina helicina and L. retroversa and b growth rates of $\mathrm{H}_{0}$ and $\mathrm{H}_{1}$ of L. helicina
Fig. 6 Individual sizes of the three cohorts of Limacina helicina present during our study. Points represent measured data. For better visualization of data, overlap of points was avoided by adding a small amount of random variation to the location of each point. Cohort $\mathrm{H}_{0}$ (individuals present from the beginning of the study) is represented in black squares $\mathrm{H}_{1}$ (hatched in September 2012) in dark grey crosses and $\mathrm{H}_{2}$ (hatched in August 2013) in light grey dots. Trend lines were added to better visualize the growth of each cohort. They represent local regressions of the size

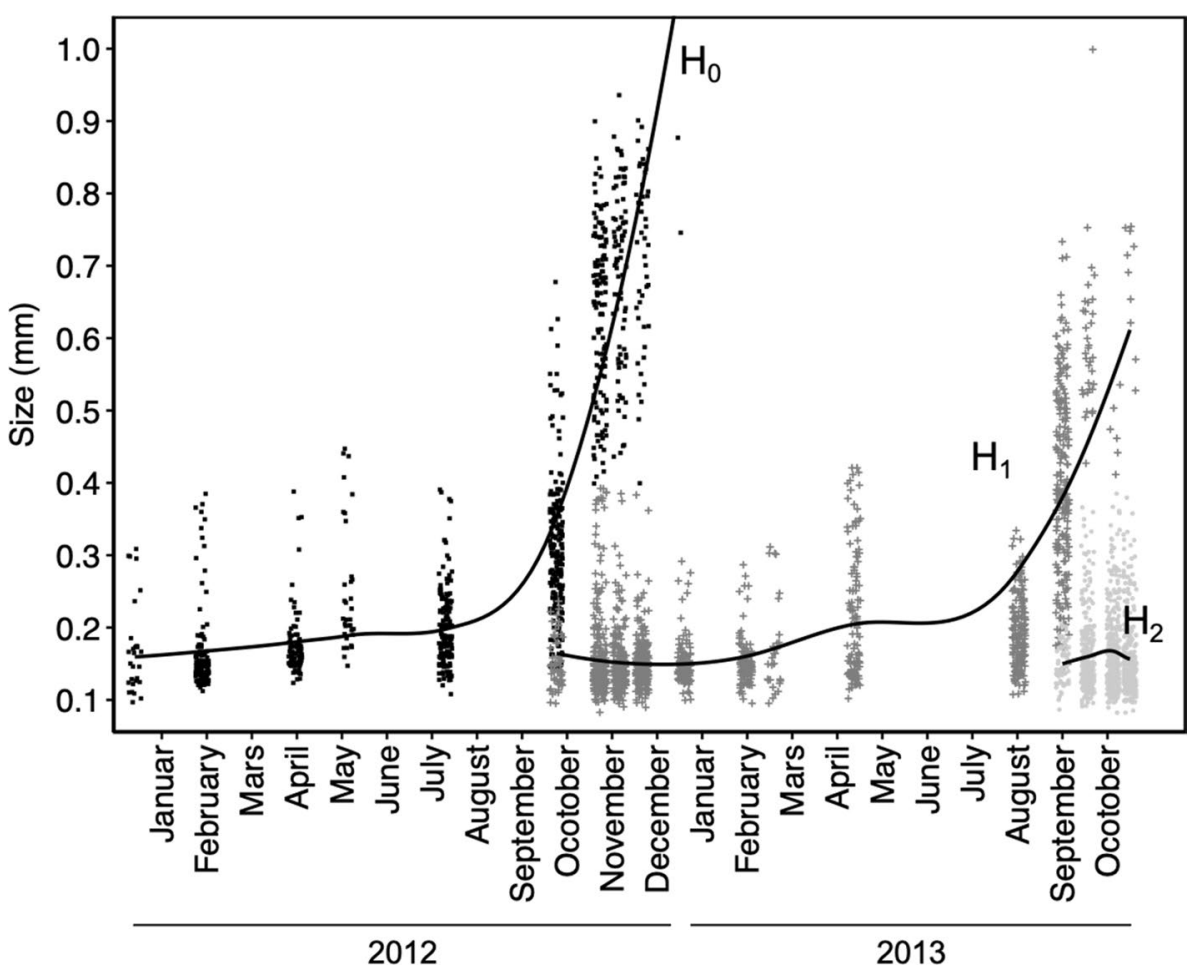

from late autumn through winter (31 October 2012 to 5 April 2013) and spring (5 April to 24 July), the growth rate was $0.0003 \mathrm{~mm} \mathrm{day}^{-1}$ (ANOVA, $F_{879}=133.8, p=0.0216$ ). In summer (24 July to 8 September), individuals had a growth rate of $0.0088 \mathrm{~mm} \mathrm{day}^{-1}$ (ANOVA, $F_{483}=364.7$, $p<0.0001)$ and reached a size of $0.60 \pm 0.10 \mathrm{~mm}$ $(n=212)$. In autumn 2013, the growth rate decreased to $0.0044 \mathrm{~mm} \mathrm{day}^{-1}$ (ANOVA, $F_{431}=781.9, p<0.0001$ ) but was still 4 times higher than during the previous autumn, when $\mathrm{H}_{1}$ first appeared. In October, individuals measured $0.73 \pm 0.07 \mathrm{~mm}(n=34)$; thus, they were 6 times bigger than after hatching. 


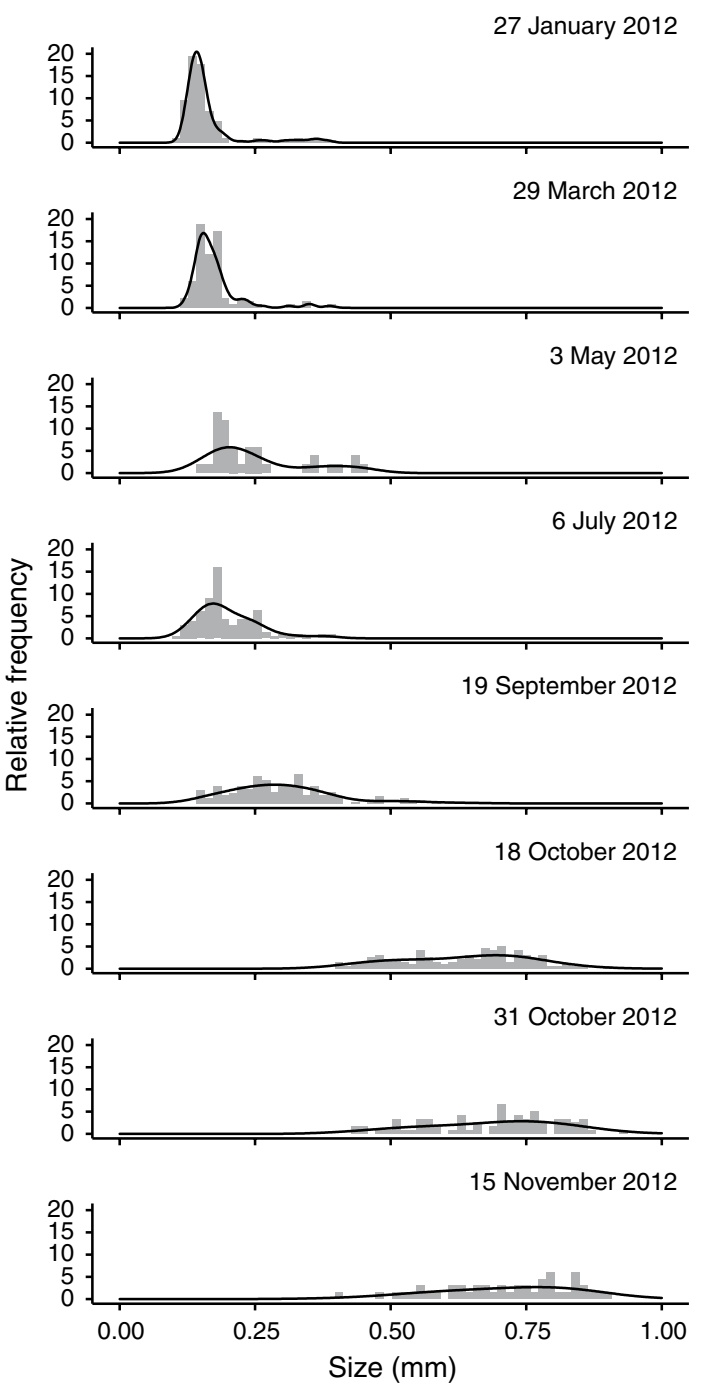

Fig. 7 Size-frequency distribution of the $\mathrm{H}_{0}$ cohort of Limacina helicina, divided into different months between January and December 2012. The modal curve fitted to the sample plot represents the probability of density of each date

The cohort $\mathrm{H}_{2}(n=1012)$ appeared in August 2013 and had an estimated mean of $0.16 \pm 0.03 \mathrm{~mm}(n=309)$, with minimum shell diameter of $0.05 \mathrm{~mm}$ (Fig. 9). Growth rate was not statistically significant until the end of the sampling period (ANOVA, $F_{1010}=0.4333, p=0.5106$ ) (Fig. 6).

The PCA analysis revealed that growth rates of $\mathrm{H}_{0}$ and $\mathrm{H}_{1}$ were positively correlated with water temperature and Julian day, while they were negatively correlated with salinity (Fig. 5). Growth rates of L. helicina were placed on the PCA in a very similar way as density of individuals, and were also positively correlated with temperature.

L. retroversa showed a random distribution of size classes for all sampling dates, hence no unimodal distribution could be fitted for this species (Fig. 10). Samples ranged between 0.48 and $1.60 \mathrm{~mm}$ shell diameter.
19 September 2012

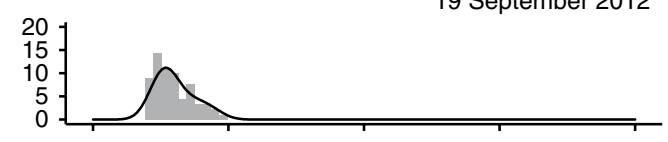

18 October 2012

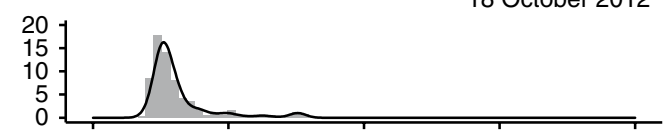

31 October 2012 to 23 January 2013
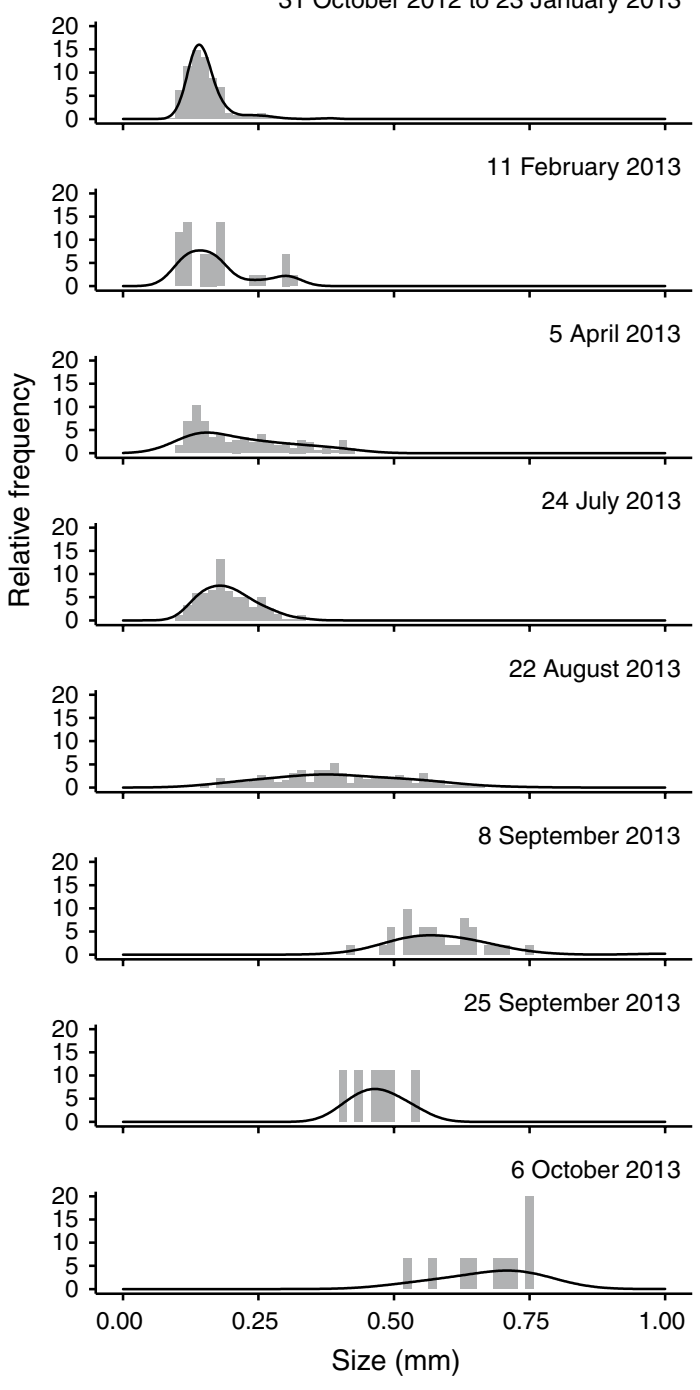

Fig. 8 Size-frequency distribution of the $\mathrm{H}_{1}$ cohort of Limacina helicina, divided into different months between September 2012 and December 2013. The modal curve fitted to the sample plot represents the probability of density of each date

\section{Discussion}

\section{Identification of $L$. helicina and $L$. retroversa}

Most of the larger individuals (85\%) were clearly identified as L. helicina characterized by a spiral shell. In addition, out of 52 small specimens $(<0.5 \mathrm{~mm})$ allocated to 


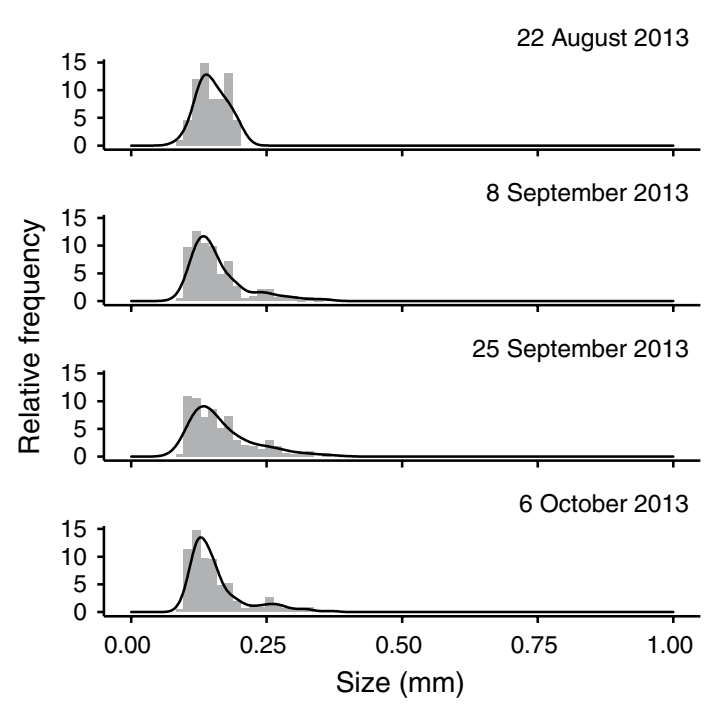

Fig. 9 Size-frequency distribution of the $\mathrm{H}_{2}$ cohort of Limacina helicina, divided into different months between September 2012 and December 2013. The modal curve fitted to the sample plot represents the probability of density of each date
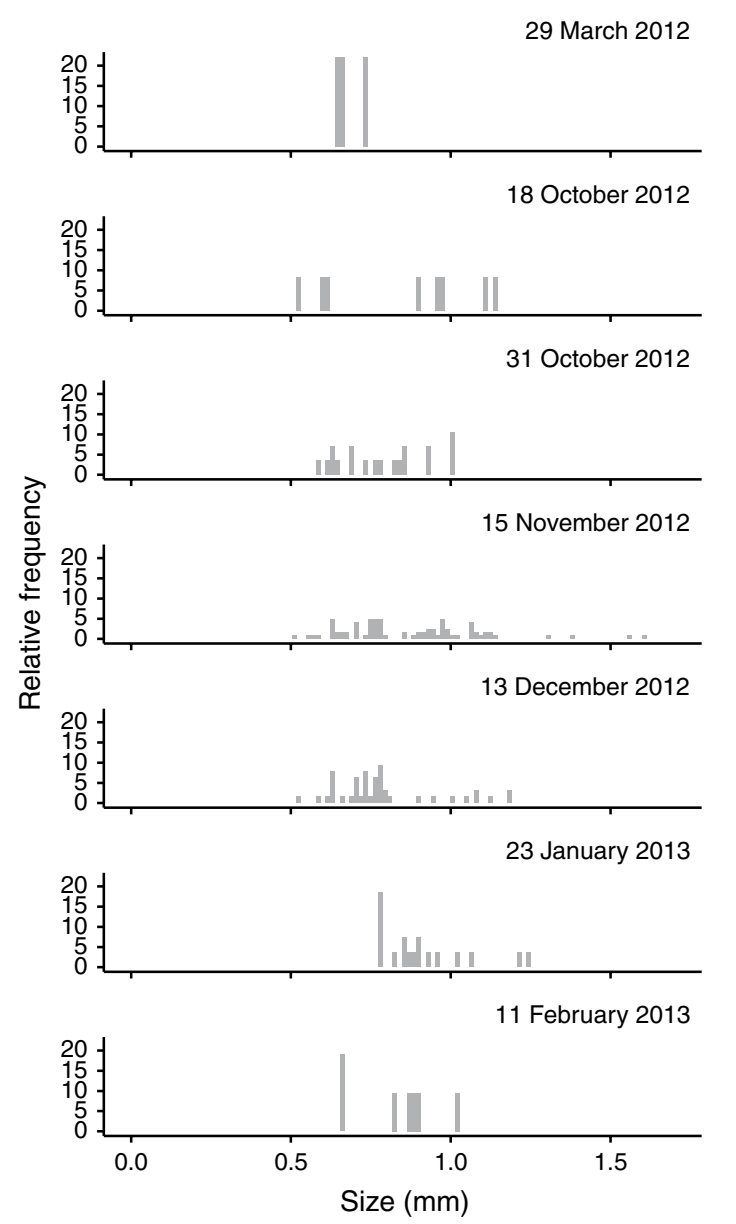

Fig. 10 Size-frequency distribution of Limacina retroversa, divided into different months between March 2012 and February 2013 molecular analysis, only one was identified as L. retroversa. Unfortunately, our samples for molecular analyses did not cover the entire sampling period but were restricted to September-December 2012. Thus, the species identification of small specimens, which did not exhibit the typical adult shell morphology is limited to these months. It is therefore possible that there were some $L$. retroversa among the small individuals during the remaining sampling period. However, Adventfjorden was mostly influenced by Arctic waters and even during the seasonal shifts in water masses, i.e., the inflow of Atlantic water, we did not observe considerable increases in large $(>0.5 \mathrm{~mm}) L$. retrovers $a$ with a pointed shell. We therefore assume that the vast majority of small Limacina individuals were indeed L. helicina during the entire study period and have analyzed the population structure accordingly.

\section{Life cycle of $L$. helicina}

Young Limacina helicina were present in Adventfjorden throughout the entire study period from January 2012 through September 2013, indicating that this species was a permanent member of the Arctic zooplankton community, in line with some other studies (Kobayashi 1974; Gilmer and Harbison 1991; Gannefors et al. 2005). Most studies, however, concluded that L. helicina is distributed patchily in both, time and space (Kattner et al. 1998; Gannefors et al. 2005; Howes et al. 2015), because L. helicina adults tend to gather in large swarms to reproduce (Dadon 1990; Dadon and de Cidre 1992; Noji et al. 1997); but, those sampling efforts were limited to only a few weeks or months and focused on the adult population. Since our high-resolution data reveal a less patchy distribution of small individuals $(<0.5 \mathrm{~mm})$ in time than previously thought, we recommend using small sized meshes in addition to larger nets, when sampling Limacina spp. populations.

Vertically, we found maximum densities of L. helicina in the sample integrating the upper $25 \mathrm{~m}$ of the water column. This layer, however, was stratified in late summer when the upper $10 \mathrm{~m}$ of the water column were characterized by warm freshwater in June-September in both years. Since salinity dilution apparently leads to an increase in negative buoyancy (Manno et al. 2012), it is possible that individuals were gathering in the colder Arctic waters below.

The densities of young L. helicina changed drastically over the year, likely as a consequence of spawning events. We observed that the maximum densities occurred in late summer/early autumn and coincided with the smallest shell diameters $(0.05 \mathrm{~mm})$. We interpret this as a result of summer/ autumn reproduction and thus hatching of the new generation, which is similar to the conclusions drawn by Gannefors et al. (2005) for the L. helicina population in Kongsfjorden. However, they only found individuals $\geq 0.2 \mathrm{~mm}$, most likely 
because of the larger nets they used for sampling, which had a mesh size of $180 \mu \mathrm{m}$. It has been suggested that the timing of reproduction of Limacina spp. depends on the feeding conditions of adults in spring (Böer et al. 2006; Bernard and Froneman 2009) as the females need to accumulate sufficient amounts of lipids (Maas et al. 2011). In a situation of low primary production, they would need to feed longer to build up sufficient lipid reserves. The earlier onset of reproduction in 2013 (August vs. September in 2012) may therefore partly relate to a higher food availability (as Chl $a$ concentrations were almost 2 times higher than in 2012) together with an earlier onset of the phytoplankton bloom, even though the PCA did not indicate a correlation between $\mathrm{Chl} a$ concentrations and population densities.

Our high-resolution data provide strong support for a non-linear growth of young L. helicina, with a growth rate of $0.0006 \mathrm{~mm} \mathrm{day}^{-1}$ within the first $10-11$ months, which accelerates thereafter to reach a maximal rate of $0.0077 \mathrm{~mm} \mathrm{day}^{-1}$ in autumn. This is similar to the results from Kobayashi (1974) who estimated a growth rate of approx. $0.001 \mathrm{~mm} \mathrm{day}^{-1}$ during the first year of development, and a higher growth rate of $0.010 \mathrm{~mm} \mathrm{day}^{-1}$ during the second year, even though he combined several years of data from stations across the Central Arctic (with $>1336$ km distance). When comparing our data to growth rates obtained in the neighboring Kongsfjorden $\left(0.013 \mathrm{~mm} \mathrm{day}^{-1}\right)$, our growth rates were lower by an order of magnitude. Differences in growth rates and life history traits may be driven by environmental conditions related to geography (Hunt et al., 2008), and can explain the rapid growth of $0.03 \mathrm{~mm}$ day $^{-1}$ observed in temperate regions (Wang et al. 2017). However, Kongsfjorden and Adventfjorden are located in close proximity and are characterized by similar light and hydrographic regimes. Kongsfjorden is generally more influenced by Atlantic waters than Adventfjorden $\left(\mathrm{S}>34.7, \mathrm{~T}>1{ }^{\circ} \mathrm{C}\right.$, Svendsen et al. 2002) but differences in temperature are small. Lower temperatures may cause some reduction in growth (as suggested by the PCA) but certainly alone cannot explain the drastic differences found between the two fjords. The factor, which we believe is most likely the most important one, is the difference in the sampling efforts. Gannefors et al. (2005) have only sampled from May through September and they have used larger mesh sizes (180 and $1000 \mu \mathrm{m})$. Thus, they have mainly collected larger, fast-growing individuals than we have. We therefore suggest that the growth rates from Gannefors et al. (2005) mirror the second year of development while our growth rates are representative for the early development of L. helicina in Arctic waters.

In contrast to a short-term study conducted in Kongsfjorden in winter (Lischka and Riebesell, 2012), we observed growth throughout the entire year, with the highest rates between September and December during the second year of the life cycle. Autumn-growth may have been supported by opportunistic feeding on small particles, which L. helicina seems to prefer (Howes et al. 2014), while winter-growth may have been possible through the use of internal lipid reserves (Boissonnot et al. 2019). During both winter and autumn, L. helicina might also be favored by little competition for feeding (Vader et al. 2015) due to the diapause of other zooplankton (Hagen and Auel 2001).

Studies conducted in the Arctic assume that the L. helicina population is composed of only one cohort at a time (Kobayashi 1974; Gannefors et al. 2005) while more recent studies conducted in the Southern Ocean argue for an overlap of $\geq 2$ cohorts (Hunt et al. 2008; Bednaršek et al. 2012). In our study, the size-frequency distributions of small individuals $(<1 \mathrm{~mm})$ indicate an overlap of 2 cohorts, the overwintering juveniles and the new-hatched veligers. At which size L. helicina reaches sexual maturity is yet unclear. According to Kobayashi (1974), L. helicina is mature at $0.8 \mathrm{~mm}$ shell diameter, while Lalli and Gilmer (1978) argue that maturation does not happen before individuals are 4-5 $\mathrm{mm}$. In our study, when a new cohort appeared as indicated by very small sizes, the individuals from the previous cohort measured $0.35 \mathrm{~mm}$ on average $(\leq 0.7 \mathrm{~mm})$, and thus very likely not ready to reproduce. We therefore conclude that mature females must have been present in order to produce the new veligers, and, hence, argue that 3 cohorts have been present in late summer/autumn. In support of this argument, large L. helicina have been regularly observed in Adventfjorden between June and August (pers. obs.). Overlapping cohorts could help to sustain a population in extremely variable ecosystems such as Arctic fjords and buffer substantial losses in offspring during 1 year (Bednaršek et al. 2012). This is particularly important for slowly developing species.

Given that in our study 1 year-old L. helicina measured about $0.8 \mathrm{~mm}$ and considering that adults can reach a size of $5 \mathrm{~mm}$ (Gannefors et al. 2005 in Kongsfjorden, pers. obs. in Adventfjorden), an average growth rate of $0.0077 \mathrm{~mm} \mathrm{day}^{-1}$ within the second year of development suggests that individuals must live approximately 2.5 years in order to reach that size. This reveals again a strong contrast with the life cycle in Kongsfjorden, where L. helicina is suggested to have a 1-year life span (Gannefors et al. 2005). It is, however, in line with Bednaršek et al. (2012) who suggested that $L$. helicina in the Southern Ocean can also be up to 3 years old.

\section{Presence of $L$. retroversa}

In Svalbard waters, the sub-polar species L. retroversa has been reported to occur episodically and at low densities (Lalli and Gilmer 1989; Kattner et al. 1998). Whether or not $L$. retroversa reproduces in polar latitudes is still under debate (Lischka and Riebesell 2012). We did not find clear indication for successful reproduction, (e.g., no sudden increase in veliger densities). Both juveniles and adults 
were present in Adventfjorden but exhibited a patchy size distribution.

Limacina retroversa is considered a marker species of Atlantic waters (Lebour 1932; Morton 1954). In agreement, we observed $L$. retroversa in autumn 2012, when Adventfjorden was influenced by Atlantic waters. The warm and saline Atlantic inflow was primarily transported into the deep layer, as also observed by Svendsen et al. (2002) and Marquardt et al. (2016). Accordingly, L. retroversa was present in higher densities in the 65-25 m layer. Limacina retroversa was not found in autumn 2013 although at that time the fjord was also influenced by Atlantic waters. The distribution of $L$. retroversa, however, is patchy in its area of origin (Meinecke and Wefer 1990), and it is thus possible that the Atlantic waters that had advected into the fjord in 2013 did not contain any specimen. It has been reported that pteropods that enter eddies are retained as juveniles or adults (Tsurumi et al. 2005). It is therefore likely that in our study, L. retroversa had been advected with Atlantic water masses, and was not able to fulfill its life cycle in these high latitudes.

In the early twentieth century, L. retroversa was regarded as a species that only occurred south of $65^{\circ} \mathrm{N}$ (Lebour 1932; Redfield 1939). However recently, L. retroversa expanded northwards and has been found in the Barents Sea and up to $79^{\circ} \mathrm{N}$ in Fram Strait during the last few decades (Bathmann et al. 1991; Bauerfeind et al. 2009). A long-term study based on sediment traps in the Fram Strait suggested that the thecosome community shifted from a dominance of $L$. helicina to a dominance of $L$. retroversa since 2005/2006 (Bauerfeind et al. 2014). This change would be associated with a warming of the water since 2000 (Schauer et al. 2008; Beszczynska-Möller et al. 2012; Bauerfeind et al. 2014). However, our study does not confirm this trend for the community in Adventfjorden. While we also observed a warm Atlantic inflow, when $L$. retroversa were present, they were on average 4 times less abundant than L. helicina. Further long-term investigations are needed to clarify this possible shift of the community composition.

\section{Conclusion}

The temporal distribution of L. helicina in Arctic waters has often been described as patchy. This seems to apply to adults, whereas veligers and juveniles are continuously present at all seasons. Our data suggest that L. helicina in Adventfjorden hatches in late summer/autumn and needs at least 2 years to reach adult size $(5 \mathrm{~mm})$. The population structure reflected the co-occurrence of two cohorts of young individuals $(<1 \mathrm{~mm})$. These veligers and juveniles grew slowly during the first 10-11 months of development, and about 10 times as fast thereafter (up to $0.0077 \mathrm{~mm} \mathrm{day}^{-1}$ in autumn). In contrast to L. helicina, L. retroversa was not able to fulfill its life cycle in
Adventfjorden and was only sporadically present during times of intrusion of Atlantic water masses. More pronounced and frequent Atlantic inflows into Arctic fjords (Spielhagen et al. 2011) could thus lead to a shift from $L$. helicina to L. retroversa, similar to what has been reported from Fram Strait (Bauerfeind et al. 2014). On the other hand, L. helicina does sustain in the Kongsfjorden, indicating that this species can thrive at Atlantic conditions. Besides warming and Atlantification, Arctic waters are also expected to acidify in future (Orr et al. 2005). Ocean acidification could reduce growth of both species due to lower calcification rates (Comeau et al. 2009; Lischka et al. 2011; Manno et al, 2012). It is thus not clear yet how Limacina spp. populations will develop in Arctic fjords. Especially L. helicina, with such slow juvenile growth and a multiyear life cycle, may be severely affected by climate change and it may be not sufficient to conduct short-term studies to address its response to environmental conditions. We therefore recommend to conduct systematic high resolution long-term studies, including veliger, juveniles and large individuals.

Supplementary Information The online version contains supplementary material available at https://doi.org/10.1007/s00300-021-02904-6.

Acknowledgements The research presented herein was part of L.B.'s $\mathrm{PhD}$ thesis at Bremen University in 2017. We are grateful for the UNIS logistical support in field, to Prof. Tove M. Gabrielsen for inviting us to take part in her IsA time series field campaign and Dr. Anna Vader and Dr. Miriam Marquardt for sharing chlorophyll $a$ data. Thanks go to the logistic team of UNIS for their excellent support in Longyearbyen and during the field campaigns of 2012 and 2013. Many thanks go to Silke Lischka, who provided additional samples for genetic examination. The study was partially funded by the Research Council of Norway (Arctic Field Grant, Svalbard Science Forum, project ID 235913/E10 and CLEOPATRA II, project ID 216537/E10) and the Helmholtz Graduate School for Polar and Marine Research. DNA extraction and sequencing was funded by the DFG grant to P.D. Dr.Michael Schroedl (DFG SCHR667/15-1). We would like to thank Silke Lischka, Brian P.V. Hunt and one additional anonymous referee for their valuable reviews, which helped to considerably improve the quality of the manuscript.

Author contributions LB, JES and BN conceived the study based on field observations performed by JES and ES on the entire mesozooplankton community. PK performed molecular analyses with the help of MS and wrote the corresponding section of material and methods. LB analyzed the pteropod distribution as well as the meteorological data, with help of $\mathrm{BN}, \mathrm{MG}$ and JES. LB, BE and $\mathrm{BN}$ interpreted the data, wrote the manuscript and revised it. All authors read and approved the manuscript.

\section{Declarations}

Conflict of interest The authors declare that there is no conflict of interest related the findings presented in this manuscript. 


\section{References}

Accornero A, Manno C, Esposito F, Gambi MC (2003) The vertical flux of particulate matter in the polynya of Terra Nova Bay. Part II. Biological components. Ant Sci 15:175-188

Akima H, Gebhardt A, Petzold T. Akima (2020) Interpolation of Irregularly and Regularly Spaced Data. R package version 0.62.1. https://cran.r-project.org/web/packages/akima/index.html. Accessed 01 Mar 2021

Bathmann UV, Noji TT, von Bodungen B (1991) Sedimentation of pteropods in the Norwegian Sea in autumn. Deep Sea Res Part A 38:1341-1360

Bauerfeind E, Nöthig EM, Beszczynska A, Fahl K, Kaleschke L, Kreker K, Klages M, Soltwedel T, Lorenzen C, Wegner J (2009) Particle sedimentation patterns in the eastern Fram Strait during 2000-2005: results from the Arctic long-term observatory HAUSGARTEN. Deep Sea Res Part I 56:1471-1487

Bauerfeind E, Nöthig EM, Pauls B, Kraft A, Beszczynska-Möller A (2014) Variability in pteropod sedimentation and corresponding aragonite flux at the Arctic deep-sea long-term observatory HAUSGARTEN in the eastern Fram Strait from 2000 to 2009. J Marine Syst 132:95-105

Bé AWH, Gilmer RW (1977) A zoogeographic and taxonomic review of euthecosomatous pteropoda. Oceanic micropaleontology, 1st edn. Academic Press, London

Bednaršek N, Tarling GA, Fielding S, Bakker DCE (2012) Population dynamics and biogeochemical significance of Limacina helicina antarctica in the Scotia Sea. DSR-II 59-60:105-116

Bednaršek N, Tarling GA, Bakker DC, Fielding S, Feely RA (2014) Dissolution dominating calcification process in polar pteropods close to the point of aragonite undersaturation. PLoS ONE 9:1-14

Bernard KS, Froneman PW (2009) The sub-Antarctic euthecosome pteropod, Limacina retroversa: Distribution patterns and trophic role. Deep Sea Res Part I 56:582-598

Berner RA, Honjo S (1981) Pelagic sedimentation of aragonite: its geochemical significance. Science 211:940-942

Beszczynska-Möller A, Fahrbach E, Schauer U, Hansen E (2012) Variability of Atlantic water temperature and transport in the entrance to the Arctic Ocean in 1997-2010. ICES J Mar Sci 69:852-863

Blachowiak-Samolyk K, Søreide JE, Kwasniewski S, Sundford A, Hop H, Falk-Petersen S, Hegseth EN (2008) Hydrodynamic control of mesozooplankton abundance and biomass in northern Svalbard waters (79-81 N). Deep Sea Res Part II 55:2210-2224

Böer M, Graeve M, Kattner G (2006) Impact of feeding and starvation on the lipid metabolism of the Arctic pteropod Clione limacina. J Exp Mar Biol Ecol 328:98-112

Boissonnot L, Niehoff B, Ehrenfels B, Søreide JE, Hagen W, Graeve M (2019) Lipid and fatty acid turnover of the pteropods Limacina helicina, L. retroversa and Clione limacina from Svalbard waters. Mar Ecol Progr Ser 609:133-149

Botev ZI, Grotowski JF, Kroese DP (2010) Kernel density estimation via diffusion. Ann Stat 38:2916-2957

Buitenhuis ET, Le Quere C, Bednaršek N, Schiebel R (2019) Large contribution of Pteropods to shallow $\mathrm{CaCO}_{3}$ export. Global Biogeochem Cycles 33(3):458-468

Byrne RH, Acker JG, Betzer PR, Feely RA (1984) Water column dissolution of aragonite. Nature 312:321-326

Chen C, Bé AW (1964) Seasonal distributions of euthecosomatous pteropods in the surface waters of five stations in the Western North Atlantic. Bull Mar Sci 14:185-220

Colgan DJ, Ponder WF, Eggler PE (2000) Gastropod evolutionary rates and phylogenetic relationships assessed using partial rDNA and histone H3 sequences. Zool Scri 29:29-63
Comeau S, Gorsky G, Jeffree R, Teyssié JL, Gattuso JP (2009) Impact of ocean acidification on a key Arctic pelagic mollusc (Limacina helicina). Biogeosc 6:1877-1882

Comeau S, Jeffree R, Teyssié J-L, Gattuso J-P, Stepanova A (2010) Response of the arctic pteropod limacina helicina to projected future environmental conditions. PLoS ONE 5(6):e11362. https:// doi.org/10.1371/journal.pone.0011362

Comeau S, Alliouane S, Gattuso JP (2012) Effects of ocean acidification on overwintering juvenile Arctic pteropods Limacina helicina. Mar Ecol Prog Ser 456:279-284

Conover RJ, Lalli CM (1972) Feeding and growth in Clione limacina (Phipps), a pteropod mollusc. J Exp Mar Biol Ecol 9:279-302

Cottier FR, Nilsen F, Skogseth R, Tverberg V, Skarðhamar J, Svendsen $H$ (2010) Arctic fjords: a review of the oceanographic environment and dominant physical processes. Geol Soc Spec Publ 344(1):35-50

Dadon JR (1990) Annual cycle of Limacina retroversa in Patagonian waters. Ame Malacol Bull 8:77-84

Dadon JR, de Cidre LL (1992) The reproductive cycle of the Thecosomatous pteropod Limacina retroversa in the western South Atlantic. Mar Biol 114:439-442

Gannefors C, Böer M, Kattner G, Graeve M, Eiane K, Gulliksen B et al (2005) The Arctic sea butterfly Limacina helicina: lipids and life strategy. Mar Biol 147:169-177

Gilmer RW, Harbison GR (1991) Diet of Limacina helicina (Gastropoda: Thecosomata) in Arctic waters in midsummer. Mar Ecol Prog Ser 77:125-134

Hagen W, Auel H (2001) Seasonal adaptations and the role of lipids in oceanic zooplankton. Zoology 104:313-326

Harbison GR, Gilmer RW (1986) Effects of animal behaviour on sediment trap collections: implications for the calculation of aragonite fluxes. Deep Sea Res A 33:1017-1024

Hop H, Falk-Petersen S, Svendsen H, Kwasniewski S, Pavlov V, Pavlova O, Søreide JE (2006) Physical and biological characteristics of the pelagic system across Fram Strait to Kongsfjorden. Prog Oceanogr 71:182-231

Hopkins TL (1985) Food web of an Antarctic midwater ecosystem. Mar Biol 89:197-212

Hopkins TL (1987) Midwater food web in McMurdo Sound, Ross Sea, Antarctica. Mar Biol 96:93-106

Hopkins TL, Torres JJ (1989) Midwater food web in the vicinity of a marginal ice zone in the western Weddell Sea. Deep Sea Res Part A 36:543-560

Howes EL, Bednaršek N, Büdenbender J, Comeau S, Doubleday A, Gallager SM, Hopcroft RR, Lischka S, Maas AE, Bijma J, Gattuso JP (2014) Sink and swim: a status review of thecosome pteropod culture techniques. J Plankton Res 36:299-315

Howes EL, Stemmann L, Assailly C, Irisson JO, Dima M, Bijma J, Gattuso JP (2015) Pteropod time series from the North Western Mediterranean (1967-2003): impacts of $\mathrm{pH}$ and climate variability. Mar Ecol Prog Ser 531:193-206

Hsiao SC (1939) The reproductive system and spermatogenesis of Limacina (Spiratella) retroversa (Flem.). Biol Bull 76:7-25

Hunt BPV, Pakhomov EA, Hosie GW, Siegel V, Ward P, Bernard K (2008) Pteropods in southern ocean ecosystems. Prog Oceanogr 78:193-221

Husson F, Josse J (2010) missMDA: handling missing values with/ in multivariate data analysis (principal component methods). $\mathrm{R}$ package version 1.2. http://www.agrocampus-ouest.fr/math/husson. Accessed 17 August 2016

IPCC (2019) Special Report on the Ocean and Cryosphere in a Changing Climate. Pörtner HO, Roberts DC, Masson-Delmotte V, Zhai P, Tignor M, Poloczanska E, Mintenbeck K, Alegría A, Nicolai M, Okem A, Petzold J, Rama B, Weyer NM (eds.). In press

Katoh K, Asimenos G, Toh H (2009) Multiple alignment of DNA sequences with MAFFT. Methods Mol Biol 537:39-64 
Kattner G, Hagen W, Graeve M, Albers C (1998) Exceptional lipids and fatty acids in the pteropod Clione limacina (Gastropoda) from both polar oceans. Mar Chem 61:219-228

Kearse M, Moir R, Wilson A, Stones-Havas S, Cheung M, Sturrock S, Buxton S, Cooper A, Markowitz S, Duran C, Thierer T, Ashton B, Mentjies P, Drummond A (2012) Geneious Basic: an integrated and extendable desktop software platform for the organization and analysis of sequence data. Bioinformatics 28:1647-1649

Knebelsberger T, Stöger I (2012) DNA extraction, preservation, and amplification. In: Kress WJ, Erickson DL (eds) DNA barcodes: methods and protocols. Humana Press, Totowa, pp 311-338

Kobayashi HA (1974) Growth cycle and related vertical distribution of the thecosomatous pteropod Spiratella ("Limacina") helicina in the central Arctic Ocean. Mar Biol 26:295-301

Lalli CM, Gilmer RW (1989) Pelagic snails: the biology of holoplanktonic gastropod mollusks. Stanford University Press, Stanford

Lalli CM, Wells FE (1978) Reproduction in genus Limacina (Opisthobranchia: Thecosomata). J Zool 186:95-108

Lancraft TM, Hopkins TL, Torres JJ, Donnelly J (1991) Oceanic micronektonic/macrozooplanktonic community structure and feeding in ice covered Antarctic waters during the winter (AMERIEZ 1988). Polar Biol 11:157-167

Lê S, Josse J, Husson F (2008) FactoMineR: an R package for multivariate analysis. J Stat Softw 25:1-18

Lebour MV (1932) Limacina retroversa in Plymouth Waters. J Mar Biol Assoc UK 18:123-126

Leikvin $\varnothing$, Evenset A (2009) Avløp fra Longyearbyen til Adventfjorden. Miljøfaglige vurderinger. Akvaplan-Niva report, Trosm $\varnothing$

Lischka S, Riebesell U (2012) Synergistic effects of ocean acidification and warming on overwintering pteropods in the Arctic. Glob Change Biol 18:3517-3528

Lischka S, Büdenbender J, Boxhammer T, Riebesell U (2011) Impact of ocean acidification and elevated temperatures on early juveniles of the polar shelled pteropod Limacina helicina: mortality, shell degradation, and shell growth. Biogeosciences 8:8178-8214

Maas AE, Elder LE, Dierssen HM, Seibel BA (2011) Metabolic response of Antarctic pteropods (Mollusca: Gastropoda) to food deprivation and regional productivity. Mar Ecol Prog Ser 441:129-139

Macdonald P, Du J (2018) Mixdist: finite mixture distribution models. $\mathrm{R}$ package version 0.5-5. http://cran.r-project.org/web/packages/ mixdist/index.html. Accessed 01 Mar 2021

Manno C, Tirelli V, Accornero A, Fonda Umani S (2010) Importance of the contribution of Limacina helicina faecal pellets to the carbon pump in Terra Nova Bay (Antarctica). J Plankton Res $32: 145-152$

Manno C, Morata N, Primicerio R (2012) Limacina retroversa's response to combined effects of ocean acidification and sea water freshening. Estuar Coast Shelf Sci 113:163-171

Marquardt M, Vader A, Stubner EI, Reigstad M, Gabrielsen TM (2016) Strong seasonality of marine microbial eukaryotes in a high-arctic fjord (Isfjorden, in West Spitsbergen, Norway). Appl Environ Microbiol 82:1868-1880

Meinecke G, Wefer G (1990) Seasonal pteropod sedimentation in the Norwegian Sea. Palaeogeogr Palaeoclimatol Palaeoecol 79:129-147

Morton JE (1954) The biology of Limacina retroversa. J Mar Biol Assoc UK 33:297-312

Nilsen F, Cottier F, Skogseth R, Mattsson S (2008) Fjord-shelf exchanges controlled by ice and brine production: the interannual variation of Atlantic Water in Isfjorden, Svalbard. Cont Shelf Res 28(14):1838-1853

Noji TT, Bathmann UV, von Bodungen B, Voss M, Antia A, Krumbholz M et al (1997) Clearance of picoplankton-sized partides and formation of rapidly sinking aggregates by the pteropod, Limacina retroversa. J Plankton Res 19:863-875

Orr JC, Fabry VJ, Aumont O, Bopp L, Doney SC, Feely RA, Gnanadesikan A, Gruber N, Ishida A, Joos F, Key RM (2005) Anthropogenic ocean acidification over the twenty-first century and its impact on calcifying organisms. Nature 437:681-686

Perissinotto R (1992) Mesozooplankton size-selectivity and grazing impact on the phytoplankton community of the Prince Edward Archipelago (Southern Ocean). Mar Ecol Prog Ser 79:243-258

R Core Team (2019) R: a language and environment for statistical computing. R Foundation for Statistical Computing, Vienna

Redfield AC (1939) The history of a population of Limacina retroversa during its drift across the Gulf of Maine. Biol Bull 76:26-47

Schauer U, Beszczynska-Möller A, Walczowski W, Fahrbach E, Piechura J, Hansen E (2008) Variation of measured heat flow through the Fram Strait between 1997 and 2006. In: Dickson RR, Meincke J, Rhines P (eds) Arctic-Subarctic Ocean Fluxes: defining the role of the Northern Seas in Climate. Springer, Dordrecht, pp 65-85

Spielhagen RF, Werner K, Sørensen SA, Zamelczyk K, Kandiano E, Budeus G, Husum K, Marchitto TM, Hald M (2011) Enhanced modern heat transfer to the Arctic by warm Atlantic water. Science 33(6016):450-453

Stübner EI, Søreide JE, Reigstad M, Marquardt M, BlachowiakSamolyk K (2016) Year-round meroplankton dynamics in highArctic Svalbard. J Plankton Res 38(3):522-536

Svendsen H, Beszczynska-Møller A, Hagen JO, Lefauconnier B, Tverberg V, Gerland S, Ørbøk JB, Bischof K, Papucci C, Zajączkowski M, Azzolini R (2002) The physical environment of Kongsfjorden-Krossfjorden, an Arctic fjord system in Svalbard. Polar Res 21:133-166

Tsurumi M, Mackas DL, Whitney FA, DiBacco C, Galbraith MD, Wong CS (2005) Pteropods, eddies, carbon flux, and climate variability in the Alaska Gyre. Deep Sea Res Part II 52:1037-1053

Vader A, Marquardt M, Meshram AR, Gabrielsen TM (2015) Key Arctic phototrophs are widespread in the polar night. Pol Biol 38:13-21

van der Spoel S (1967) Euthecosomata: A group with remarkable developmental stages (Gastropoda, Pteropoda). Zoological Museum, Amsterdam

van der Spoel S, Dadon JR (1999) Pteropoda. In: Boltovskoy D (ed) South Atlantic zooplankton. Backhhuys, Leiden

Walkusz W, Kwasniewski S, Falk-Petersen S, Hop H, Tverberg V, Wieczorek P, Węsławski JM (2009) Seasonal and spatial changes in the zooplankton community of Kongsfjorden, Svalbard. Polar Res 28:254-281

Wang K, Hunt BP, Liang C, Pauly D, Pakhomov EA (2017) Reassessment of the life cycle of the pteropod Limacina helicina from a high resolution interannual time series in the temperate North Pacific. ICES J Mar Sci 74(7):1906-1920

Publisher's Note Springer Nature remains neutral with regard to jurisdictional claims in published maps and institutional affiliations. 